\title{
Survival rates of mouse blastocyst vitrified in dimethylformamide based solutions associated with ethylene glicol or 1-2 propanediol
}

\author{
Sobrevivência de embriões de camundongo vitrificados em soluções com dimetilformamida associadas ao \\ etilenoglicol ou 1-2 propanediol
}

\author{
Paula Rodriguez Villamil $^{*}$ Felipe Ledur Ongaratto ${ }^{I}$ Daniela Scherer da Silva ${ }^{I}$ Berenice de Avila \\ Rodrigues $^{I}$ Jose Luiz Rodrigues ${ }^{I}$
}

\begin{abstract}
The aim of this study was to determine the effect of dimethylformamide $(D F)$ associated with ethylene glycol (EG) or 1-2 propanediol (PROH) during vitrification, on the in vitro development of mouse blastocysts. Cryoprotectant toxicity was evaluated exposing embryos into three different equilibrium solutions (ES) composed by DF, EG or PROH mixtures (10\% $v / v$ of each) in $m P B S+0.5 \%$ PVA at different interval times $(1$, 3 and 10min). In a second experiment, embryos were exposed to the same ES (either 1 or $3 \mathrm{~min}$ ), following for the three respectively vitrification solutions (VS) (20\% v/v of each) for 30s. After 72 hours of in vitro culture, embryo hatching and expansion rates were similar for the ES1 and ES2 equilibration solutions during the time interval of 1 or 3 min. However embryos exposed for $10 \mathrm{~min}$ to the DF equilibration solutions, had lower survival rates than EG-PROH solution $(P<0.01)$. Furthermore, survival rates for embryos exposed to DF-PROH $(E S+V S)$ were lower than embryos exposed to the other solutions $(P<0.01)$. Blastocyst vitrification was performed with the three ES+VS (for $1 \mathrm{~min}$ and 30s, respectively), using glass micropipettes (GMP). Survival rates were lower for blastocysts vitrified with DF solutions (3\%-3/108 and 17.1\%-19/111) $(P<0.01)$ than with PROH $+E G$ vitrification solutions (69\%73/105). In conclusion, DF as a cryoprotectant into vitrification solutions have deleterious effects on the in vitro developmental competence of vitrified mouse blastocysts.
\end{abstract}

Key words: mouse, blastocyst, vitrification, dimethylformamide, glass micro pipettes.

RESUMO

O objetivo deste estudo foi determinar o efeito da dimetilformamida (DF) associada com etileno glycol (EG) ou 1-2 propanediol (PROH) durante a vitrificação, no desenvolvimento in vitro de blastocistos murinos. A toxicidade dos crioprotetores foi avaliada ao expor os embriões as três soluções de equilíbrio (ES) compostas pelas misturas de DF, EG ou PROH (10\% v/v de cada) em mPBS + 0,5\% PVA, em diferentes intervalos de tempo (1, 3 e 10min). Em um segundo experimento, os embrioes foram expostos as mesmas ES (durante 1 e $3 \mathrm{~min}$ ), seguido da exposição as três respectivas soluções de vitrificação (VS) $(20 \% \mathrm{v} / \mathrm{v}$ de cada) durante $30 \mathrm{seg}$. Após 72 horas de cultivo in vitro, as taxas de expansão e eclosão dos embrióes expostos durante os períodos de 1 e 3 min às soluções de equilíbrio ES1 e ES2 foram semelhantes. No entanto, os embriões expostos durante 10min às soluções de equilíbrio com DF apresentaram taxas de sobrevivência inferiores à solução de EG-PROH $(P<0,01)$. Além disso, as taxas de sobrevivência dos embriões expostos à DF-PROH (ES+VS) foram menores que as dos embriões expostos as outras soluções $(P<0,01)$. A vitrificação dos blastocistos foi realizada após a exposição dos embriões nas três ES+VS (por lmin e $30 \mathrm{seg}$, respectivamente), usando micropipetas de vidro (GMP). As taxas de sobrevivência foram menores nos blastocistos vitrificados nas soluções compostas por DF (3\%-3/108 e $17,1 \%-19 / 111)$, em relação à solução EG-PROH (69\%-73/ 105) $(P<0,01)$. Em conclusão, a DF adicionada como crioprotetor às soluções de vitrificação apresenta efeitos deletérios na capacidade de desenvolvimento in vitro dos blastocistos murinos vitrificados.

Palavras-chave: camundongos, blastocistos, vitrificação, dimetilformamida, micropipetas de vidro.

\section{INTRODUCTION}

Over the last 20 years numerous modifications have been introduced in the embryo cryopreservation process, in an attempt to improve

'Laboratório de Embriologia e Biotecnicas da Reprodução, Faculdade de Veterinária, Universidade Federal do Rio Grande do Sul (UFRGS), CP 15004, 91501-970, Porto Alegre, RS, Brasil. E-mail: prodriguezv@unal.edu.co. *Autor para correspondência. 
survival rates and simplifying procedures. Vitrification is an simple method for cryopreservation of mammalian embryos, described as a physical process that solidifies a solution at low temperatures not by crystallization but by extreme elevation in viscosity during cooling (RALL \& FAHY, 1985). According to WOODS et al. (2004) to obtain this amorphous state, higher concentration of cryoprotectant agents ( 4 to $8 \mathrm{M}$ ) than needed for traditional freezing ( 1 to $2 \mathrm{M}$ ) is required. These concentration levels would prevent ice crystal formation; however this would probably cause cell damage due to osmotic and cytotoxic injuries (KASAI \& MUKAIDA, 2004).

To minimize these harmful effects many strategies have been developed, based on the use of lower toxicity cryoprotectants, and establishing optimal sample volume, concentration levels, temperature and interval exposure time (LIEBERMANN et al., 2003). The use of cryoprotectant solutions with lower molecular weight is one of these strategies, allowing to minimize exposure time, reducing cryoprotectant concentration and preventing osmotic swelling (KASAI \& MUKAIDA, 2004). Among the permeable cryoprotectants, $\mathrm{EG}(\mathrm{w}=62.02), \mathrm{DF}(\mathrm{w}=73.1)$ and $\mathrm{PROH}$ $(\mathrm{w}=76.10)$ have the lower molecular weight as compared with Dimethylsulfoxide (DMSO) (w=78.13) and Glycerol (GLY) (w=92.10) (BAUDOT et al., 2000). Furthermore, association of two or more of these agents should decrease individual specific toxicity. According to some researches, the mixture permeability is higher than that of its individual components (VAJTA \& NAGY, 2006).

The most common association for vitrification solutions contains EG and DMSO. Such components could be associated or replaced by other higher molecular weight cryoprotectants such as $\mathrm{PROH}$ and DF, taking into account their similar glass forming with DMSO. PROH is one of the most stable glassforming agents (BOUTRON, 1984), being also less toxic and more permeable than DMSO. DF is another cryoprotectant with a high glass-forming trend (BAUDOT \& BOUTRON, 1998). DF was previously successfully used in slow freezing of stallion semen (SQUIRES et al., 2004) and for vitrification of bovine oocytes (SIQUEIRA-PYLES et al., 2004), ovine embryos (ARAUJO-LEMOS, 2010) and fish embryos associated to DMSO (DING et al., 2007). However, the effects of DF on mouse embryo vitrification are still unknown. The aim of this experiment was to determine, if DF based solutions would be efficient as cryoprotectant in association with EG and $\mathrm{PROH}$, and his effect on in vitro viability of vitrified mouse blastocysts.

\section{MATERIALS AND METHODS}

Except where otherwise indicated, all chemicals were obtained from Sigma-Aldrich Chemical Co. (St. Louis, MO, USA). Culture media and solutions were prepared using water purified by Milli-Q synthesis system (Millipore, Bedford, MA, USA).

Production of mouse Embryos

For this experiment were used Mus musculus domesticus, swiss albino strain males $(2-10 \mathrm{mo})$ and fertile females (6-8 wks). They were kept under controlled temperature and light conditions with food and water ad libitum. Females were superovulated by intraperitoneal 10IU injection of equine chorionic gonadotropin (eCG - Folligon ${ }^{\circledR}$, Intervet) followed $46 \mathrm{~h}$ later by intraperitoneal 10IU injection of human chorionic gonadotropin (hCG - Chorulon ${ }^{\circledR}$, Intervet), then donors were mated overnight. Ninety-six hours after hCG injection, females were subjected to cervical dislocation and uterine horns were flushed individually with $0.5 \mathrm{~mL}$ mPBS medium. Blastocyst of excellent morphological quality as described ROBERTSON \& NELSON (1998) were randomly allocated into experimental groups.

Toxicity test of vitrification solution

Selected groups of embryo were exposed in a first experiment at $37^{\circ} \mathrm{C}$ for $1 \mathrm{~min}(\mathrm{n}=51 ; 57$ and 53), $3 \min (\mathrm{n}=56 ; 57$ and 58$)$ or $10 \mathrm{~min}(\mathrm{n}=49 ; 56$ and 58$)$ in one of the following equilibration solutions: ES1 (10\% $\mathrm{PROH}+10 \% \mathrm{DF}), \mathrm{ES} 2(10 \% \mathrm{EG}+10 \% \mathrm{DF})$ or ES3 (10\% $\mathrm{PROH}+10 \% \mathrm{EG})$, respectively. In a second experiment, embryos were exposed to the same equilibration solutions for $1 \mathrm{~min}(\mathrm{n}=28 ; 24$ and 25$)$ or $3 \mathrm{~min}(\mathrm{n}=24 ; 27$ and 25) followed for a period of $30 \mathrm{~s}$ into the vitrification solutions: VS1 (20\% PROH + 20\% DF), VS2 (20\% EG + $20 \% \mathrm{DF})$ or VS3 (20\% PROH $+20 \% \mathrm{EG})$, respectively. The solutions were composed by cryoprotectants diluted into $\mathrm{mPBS}+0.5 \%$ PVA. After exposure, embryos were transferred to $\mathrm{mPBS}+0.25 \mathrm{M}$ sucrose, and after $5 \mathrm{~min}$, embryos were washed in $\mathrm{mPBS}$ and placed into KSOM medium droplets for in vitro culture. Embryos from control group immediately after collection were transferred to KSOM medium and in vitro cultured without any treatment. Re-expansion and hatching rates were evaluated after $72 \mathrm{~h}$ of in vitro culture.

Vitrification and warming procedure

The vitrification procedure was based on open pulled straw (OPS) technology originally described by (VAJTA et al., 1998) with modifications. OPS were replaced by GMPs, that were made from 
capillary tubes softened by heat, and pulled manually until its outer diameter reached approximately $0.6 \mathrm{~mm}$. Embryos were distributed into three different vitrification experimental groups and a control group. Control group: embryos were transferred to KSOM medium drops for in vitro culture without any treatment immediately after collection. Group 1: embryos were exposed to ES1 for 1min, followed by VS1 for 30sec; Group 2: embryos were exposed to ES2 for 1min followed by VS2 for 30sec; and Group 3: embryos were exposed to ES3 for $1 \mathrm{~min}$, followed by VS3 for $30 \mathrm{sec}$. After exposure at $37^{\circ} \mathrm{C}$, embryo was loaded by capillarity, placing the narrowest end of capillary tubes into $2 \mu \mathrm{L}$ VS droplets, to be plunged into super-cooled nitrogen (LN2) as described by (ARAV et al., 2000). After warming the embryos were placed into $300 \mu \mathrm{L}$ droplets of mPBS supplemented with $0.25 \mathrm{M}$ sucrose for cryoprotectant dilution. Finally, control group $(\mathrm{n}=123)$ and vitrified embryos ( $\mathrm{n}=\mathrm{VS} 1(108)$; VS2(111); VS3(105)) were in vitro cultured in $100 \mu \mathrm{L}$ droplets of KSOM medium supplemented with $0.4 \%$ of BSA, under oil, at $37^{\circ} \mathrm{C}, 5 \% \mathrm{CO} 2,5 \% \mathrm{O} 2$ and $90 \% \mathrm{~N} 2$ and saturated humidity. The re-expansion and hatching rates were examined at $24 \mathrm{~h}$ intervals during $72 \mathrm{~h}$.

Differential ICM and TE cell counts

A sample $(n=64)$ of viable expanded and hatched embryos, $(n=31,15$ and 18 for Control group, ES2/EV2 and ES3/EV3, respectively), were differentially stained for counting trophectoderm (TE) and inner cell mass (ICM) nuclei; whereas blastocyst exposed to ES1/ VS1 solutions were not stained after thawing due to the low survival rate. Blastocysts were differentially stained using ionic detergent, Triton-X 100 and fluorochromes, Hoechst 33342 and propidium iodide, as previously described (THOUAS et al., 2001). Stained blastocysts were placed on a glass slide containing a drop of glycerol and gently flattened with a coverslip before being examined under fluorescence microscopy.

\section{Statistical analysis}

Re-expansion and hatching rates were compared by Chi-square test, for a significance level of $\mathrm{P}<0.01$. Total cell numbers, ICM and trophectoderm mean cells numbers \pm SEM between vitrification groups were analyzed by ANOVA. The normality of values distribution was previously tested by using ShapiroWilk test. The LSD Fisher test was used for subsequent multiple comparisons when analysis of variance revealed statistically significant differences $(\mathrm{P}<0.05)$.

\section{RESULTS}

Embryo in vitro survival rates after exposure to different equilibrium solutions are shown in table 1 . No relevant differences were observed between blastocysts re-expansion or hatching rates, after 1 or $3 \mathrm{~min}$ exposure to different equilibrium solutions. However, 10min exposure time into DF based equilibrium solutions led to a significant reduction in embryo re-expansion and hatching rates. Furthermore, embryo in vitro survival rates after exposure to different equilibrium and vitrification solutions are shown in table 2. In this case, results shown significant lower survival rates for the embryos exposed into PROH-DF solution (ES1/VS1) when compared with the other groups $(\mathrm{P}<0.05)$.

Embryo viability observed $72 \mathrm{~h}$ after thawing and in vitro culture is summarized in table 3 . Blastocysts vitrified after exposure to ES3/VS3 solutions showed higher survival rates than the other vitrification solutions. Furthermore, DF containing cryoprotectant solutions led to a significant reduction in embryo reexpansion and hatching rates, when compared to control group and to ES3/VS3 vitrified embryos.

Table 1 - Embryo re-expansion and hatching rates after exposure to equilibration solution at three different time intervals (5 replicates).

\begin{tabular}{|c|c|c|c|c|c|c|}
\hline \multirow{3}{*}{ Solutions } & \multicolumn{3}{|c|}{ №. of embryos re-expanded / $\mathrm{n}$ - of embryos treated (\%) } & \multicolumn{3}{|c|}{ №. of embryos hatched / $\mathrm{n}$ o of embryos treated (\%) } \\
\hline & \multicolumn{3}{|c|}{------------------------Exposure time------------------------ } & \multicolumn{3}{|c|}{------------------------Exposure time------------------------ } \\
\hline & $1 \mathrm{~min}$ & $3 \mathrm{~min}$ & $10 \mathrm{~min}$ & $1 \mathrm{~min}$ & $3 \min$ & $10 \mathrm{~min}$ \\
\hline ES1 & $49 / 51^{\mathrm{a}}(96)$ & $47 / 56^{\mathrm{a}}(84)$ & $0 / 49^{\mathrm{c}}(0)$ & $36 / 51^{\mathrm{b}}(70)$ & $42 / 56^{\mathrm{a}}(75)$ & $0 / 49^{\mathrm{c}}(0)$ \\
\hline ES2 & $56 / 57^{\mathrm{a}}(98)$ & $57 / 57^{\mathrm{a}}(100)$ & $15 / 56^{\mathrm{b}}(26)$ & $50 / 57^{\mathrm{a}}(87)$ & $46 / 57^{\mathrm{a}}(80)$ & $8 / 56^{\mathrm{c}}(14)$ \\
\hline ES3 & $53 / 53^{\mathrm{a}}(100)$ & $58 / 58^{\mathrm{a}}(100)$ & $56 / 58^{\mathrm{a}}(96)$ & $43 / 53^{\mathrm{a}}(81)$ & $47 / 58^{\mathrm{a}}(81)$ & $44 / 58^{\mathrm{b}}(76)$ \\
\hline Control & \multicolumn{3}{|c|}{-} & \multicolumn{3}{|c|}{$47 / 52^{\mathrm{a}}(92)$} \\
\hline
\end{tabular}

ES1 $=10 \%$ PROH $+10 \%$ DF, ES2 $=10 \%$ EG + 10\% DF, ES3=10\% PROH + 10\% EG. The solutions were composed by cryoprotectants diluted in mPBS containing $0.5 \%$ PVA

a,b,c Numbers in the same column without common superscripts differ, $\mathrm{P}<0.01$. 
Table 2 - Embryo re-expansion and hatching rates after exposure to the equilibration and vitrification solutions (3 Replicates)

\begin{tabular}{|c|c|c|c|c|}
\hline \multirow{3}{*}{ Solutions } & \multicolumn{2}{|c|}{ №. of embryos re-expanded / $n^{\circ}$. of embryos treated (\%) } & \multicolumn{2}{|c|}{ №. of embryos hatched / $\mathrm{n}^{\circ}$. of embryos treated (\%) } \\
\hline & \multicolumn{2}{|c|}{----------------Exposure time to ES-------------- } & \multicolumn{2}{|c|}{ 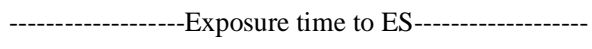 } \\
\hline & $1 \mathrm{~min}$ & $3 \min$ & $1 \mathrm{~min}$ & $3 \mathrm{~min}$ \\
\hline $\mathrm{ES} 1+\mathrm{VS} 1(30 \mathrm{~s})$ & $22 / 28(78)^{\mathrm{a}}$ & $18 / 24(75)^{\mathrm{a}}$ & $17 / 28(61)^{\mathrm{b}}$ & $14 / 24(58)^{\mathrm{b}}$ \\
\hline $\mathrm{ES} 2+\mathrm{VS} 2(30 \mathrm{~s})$ & $19 / 24(79)^{\mathrm{a}}$ & $21 / 27(77)^{\mathrm{a}}$ & $17 / 24(71)^{\mathrm{a}}$ & $18 / 27(66)^{\mathrm{a}}$ \\
\hline $\mathrm{ES} 3+\mathrm{VS} 3(30 \mathrm{~s})$ & $22 / 25(88)^{\mathrm{a}}$ & $20 / 25(80)^{\mathrm{a}}$ & $19 / 25(76)^{a}$ & $17 / 25(68)^{\mathrm{a}}$ \\
\hline Control & & & \multicolumn{2}{|c|}{$27 / 30(90)^{\mathrm{a}}$} \\
\hline
\end{tabular}

$\mathrm{ES} 1=10 \% \mathrm{PROH}+10 \% \mathrm{DF}, \mathrm{VS} 1=20 \% \mathrm{PROH}+20 \% \mathrm{DF} ; \mathrm{ES} 2=10 \% \mathrm{EG}+10 \% \mathrm{DF}, \mathrm{VS} 2=20 \% \mathrm{EG}+20 \% \mathrm{DF} ; \mathrm{ES} 3=10 \% \mathrm{PROH}+10 \% \mathrm{EG}$ VS3 $=20 \% \mathrm{PROH}+20 \%$ EG. The solutions were composed by cryoprotectants diluted in mPBS containing $0.5 \%$ PVA

${ }_{a, b}$ Numbers in the same column without common superscripts differ, $\mathrm{P}<0.01$.

Differential cell counts of total, ICM and TE cell numbers showed significant differences $(\mathrm{P}<0.05)$ between control and vitrified embryos in ES2/SV2 or ES3/VS3. Total cell numbers was (87.4 \pm 7.49$),(72.9 \pm 4.3)$, (73.9 \pm 4.8$)$, respectively for the groups; for TE the mean \pm (SEM) of cells was $(63.7 \pm 5.3),(51.5 \pm 2.7)$ and (52.5 \pm 3.9$)$, and also for ICM cell numbers was (23.7 \pm 3.1$)$ for control group, $(21.4 \pm 2.3)$ for ES2/VS2 group and (21.4 \pm 2.6$)$ for $\mathrm{ES} 3 / \mathrm{VS} 3$ group.

\section{DISCUSSION}

Since the first successful embryo vitrification (RALL \& FAHY, 1985), the description of cryoprotectant associations, nontoxic and stable enough to avoid ice formation and preserve embryo viability, has been challenging. In order to find a suitable association, our study tested DF associated with EG or PROH to vitrify mouse blastocysts. First we examined the DF glass-forming ability in association with EG or PROH through visual inspection, as previously reported (JIN et al., 2008; SEKI \& MAZUR, 2008). Our results showed that a $20 \%$ DF presence in vitrification solutions was sufficient to achieve vitreous state. Higher DF concentrations such as 30\% in association with PROH (20\% v/v), were unstable and crystallized during the warming process, probably due to elevated glass forming tendencies of these two cryoprotectants (BAUDOT et al., 2000). This result was not similar for $30 \% \mathrm{DF}+20 \% \mathrm{EG}$ association due to the fact that $\mathrm{EG}$ is weak glass-forming, and showed lower presence of hydrate forms. Taking into account these observations, in order to avoid toxicity and osmotic stress, but ensuring adequate vitrification on the medium, we decided to use the minimal cryoprotectant concentration required for satisfactory vitrifying after exposure to $\mathrm{LN}_{2}$.
Cryoprotectant toxicity is another important factor for successful vitrification. It is difficult to predict responses of individual cryoprotectant agents or mixtures, depending on multiple variables as concentration, exposure time, temperature, and embryo traits such as developmental stage and membrane permeability (FAHY et al., 2004; BERTOLINI et al., 2005). Furthermore, first we examined embryo survival rates after exposure at different interval times to the equilibrium solutions and after the exposure to the equilibrium and vitrification solutions. Re-expansion and hatching rates after 1 or $3 \mathrm{~min}$ exposure times into equilibrium solutions showed no significant differences between experimental $\mathrm{ES} 2+\mathrm{VS} 2$ and $\mathrm{ES} 3+\mathrm{VS} 3$ groups, demonstrating that these exposure times were harmless to embryo development ability. However, embryos exposed for 10min to DF containing cryoprotectant solutions showed significantly lower survival rates. These findings indicated that DF specific toxicity is higher than other cryoprotectants. Nevertheless, this

Table 3 - Embryo re-expansion and hatching rates after vitrification (5 replicates).

\begin{tabular}{lccc}
\hline Treatments & Embryos N & $\begin{array}{c}\text { Re-expanded } \\
\text { embryos N (\%) }\end{array}$ & $\begin{array}{c}\text { Hatched } \\
\text { embryos N }(\%)\end{array}$ \\
\hline ES1+VS1 & 108 & $13^{\mathrm{c}}(12)$ & $3^{\mathrm{d}}(3)$ \\
ES2+VS2 & 111 & $46^{\mathrm{b}}(38)$ & $19^{\mathrm{c}}(17)$ \\
ES3+VS3 & 105 & $89^{\mathrm{a}}(84)$ & $73^{\mathrm{b}}(69)$ \\
Control & 123 & - & $113^{\mathrm{a}}(92)$ \\
\hline
\end{tabular}

$\mathrm{ES} 1=10 \% \quad \mathrm{PROH}+10 \% \quad \mathrm{DF}, \quad \mathrm{VS} 1=20 \% \quad \mathrm{PROH}+20 \% \quad \mathrm{DF}$ $\mathrm{ES} 2=10 \% \quad \mathrm{EG}+10 \% \quad \mathrm{DF}, \mathrm{VS} 2=20 \% \quad \mathrm{EG}+20 \% \quad \mathrm{DF} ; \mathrm{ES} 3=10 \%$ $\mathrm{PROH}+10 \%$ EG, VS3= 20\% PROH+20\% EG. The solutions were composed by cryoprotectants diluted in mPBS containing $0.5 \%$ PVA

a,b,c,d Numbers in the same column without common superscripts differ, $\mathrm{P}<0.01$.

Ciência Rural, v.41, n.11, nov, 2011. 
could be controlled, as previously described, by reducing embryo exposure time (KASAI \& MUKAIDA, 2004; LIEBBERMAN et al., 2003). Therefore, when embryos were exposed to the entire cryoprotectant solutions, survival rates were similar for solutions composed with EG and significant lower for PROH-DF cryoprotectant association. These results confirm the previously described by other authors (EMILIANI et al., 2000; CHIAN et al., 2004), Where EG presence in cryoprotectant solutions showed lower toxicity effects on in vitro viability.

In vitro embryo survival rates after vitrification showed that the cryoprotectant solutions ES3/VS3 were most suitable to preserve embryo development ability (Table 3). These data demonstrated EG efficiency associated with PROH as cryoprotectant solution for blastocysts vitrification, and confirmed previously reported observations (ISHIMORI et al., 1992). Nevertheless, hatching rate of vitrified blastocysts in our experiment, 70\% (73/105), was higher than reported by ISHIMORI et al. (1992) (46\%), LANGE (2008) (42,9\%) and NIVIA (2008), that used $1 \mathrm{~min}(37 \%)$ or $3 \mathrm{~min}(60 \%)$ exposure to equilibrium solution. Furthermore, cryoprotectant solutions containing DF (ES1/VS1 and ES2/VS2) were not appropriate to vitrify mouse blastocysts. The most probable reason for this viability decrease could be due not only to the toxicity of such cryoprotectant, but due to solution crystallization during warming procedure. This crystallization process was clear on vitrification solutions test, when $30 \%$ DF in association with $20 \%$ $\mathrm{PROH}$ were unstable during thawing process. However, transparent appearance for $20 \%$ DF solutions does not exempt from crystallization, since visual inspection does not detect devitrified samples when crystals are smaller than wavelength for visible light rays; they may be present, but not visible (JIN et al., 2008).

Due to higher water bonding compounds, DF had a higher glass-forming tendency than other cryoprotectans as Glycerol and EG (BAUDOT \& BOUTRON, 1998), but also a higher incidence of hydrates forms. According with SUKHNO et al. (2008), the common association of DF with water is a stable combination containing two or three molecules of water DF- $\left(\mathrm{H}_{2} \mathrm{O}\right)_{2}$ or DF- $\left(\mathrm{H}_{2} \mathrm{O}\right)_{3}$, demonstrating that water-DF system could be an efficient glass former as waterDMSO. However, hydrates forms observed in DF solutions showing thermograms more complicated than DMSO. Due to hydrates formation, two melting points could appear during warming process; one at temperatures of $-49.5^{\circ} \mathrm{C}$ and the second at $-47,7^{\circ} \mathrm{C}$, represented a crystallization peak of solution, and probably a devitrification due to the presence of ice forms (BAUDOT \& BOUTRON, 1998), this could explain the lower survival rates of DF containing solutions trough the thawing process as compared with PROH-EG cryoprotectant solution. However, it would be possible to circumvent these two melting peaks of ice and hydrate forms, using higher warming rates $\left(>20.000^{\circ} \mathrm{C} \mathrm{min}^{-1}\right)$. According to SEKI \& MAZUR (2008) the rapid warming would minimize both the formation of intracellular ice crystals by devitrification and their growth to lethal size by crystallization. Other proposed could be, the use of other cryoprotectant association with DF, like macromolecules that would be improve the glass forming, avoid intracellular hydrates forms, and probably reduce the specific DF toxicity. For this reason future experiments are needed to understand more DF behavior.

Harmful effects of vitrification solutions or vitrification procedure per se may impair development kinetics, causing viable embryos to delay development (BERTOLINI et al., 2005). Taking into account this information, we have differentially stained embryos to obtain more accurate information about embryo quality and embryo cell differentiation. Results showed that vitrified embryos, disregarding cryoprotectant solution, had significantly lower ICM and TE cells counts than embryos in control group. This decrease of blastomer is probably a consequence of cell membranes cryoinjuries during cooling and warming procedures (MAZUR, 1970), that negatively affect further embryo development (KAIDI et al., 2001).

\section{CONCLUSION}

In the conditions of this study, cryoprotectant solutions containing DF were not suitable to preserve mouse blastocyst viability after vitrification.

\section{REFERENCES}

ARAÚJO-LEMOS, P.F.B. et al. Avaliação ultraestrutural de embriões ovinos criopreservados pelo método clássico e pela vitrificação. Acta Scientiae Veterinariae, Porto Alegre, v.38, s2, p.809, 2010.

ARAV, A. et al. A new device and method for vitrification increases the cooling rate and allows successful cryopreservation of bovine oocytes. Theriogenology, v.53, p.248, 2000.

BAUDOT, A.; BOUTRON, P. Glass-forming tendency and stability of aqueous solutions of Diethylformamide and Dimethylformamide. Cryobiology, v.37, p.187-199, 1998.

BAUDOT, A. et al. Glass-forming tendency in the system water-dimethyl sulfoxide. Cryobiology, v.40, p.151-158, 2000 . 
BERTOLINI, M. et al. In vitro and in vivo survival of mouse morulas and blastocysts following vitrification in $45 \%$ glycerol. Acta Scientiae Veterinariae, v.33, p.245-251, 2005.

BOUTRON, P. More accurate determination of the quantity of ice crystallized at low cooling rates in the glycerol and 1,2propanediol aqueous solutions: comparison with equilibrium. Cryobiology, v.21, p.183-191, 1984.

CHIAN, R. et al. High survival rate of bovine oocytes matured in vitro following vitrification. Journal of Reproduction and Development, v.50, p.685-696, 2004.

DING, F.H.et al. Preliminary studies on the vitrification of red sea bream Pagrus major embryos. Theriogenology, v.68, p.702-708, 2007.

EMILIANI, S. et al. Comparison of ethylene glycol, 1,2propanediol and glycerol for cryopreservation of slow-cooled mouse zygotes, 4-cell embryos and blastocysts. Human Reproduction, v.15, p.905-910, 2000.

FAHY, R. et al. Improved vitrification solutions based on the predictability of vitrification solution toxicity. Cryobiology, v.48, p.22-35, 2004

ISHIMORI, H. et al. Viability of vitrified mouse embryos using various cryoprotectant mixtures. Theriogenology, v.37, p.481-487, 1992 .

JIN, B. et al. Formation of extracellular and intracellular ice during warming of vitrified mouse morulae and its effect on embryo survival. Cryobiology, v.56, 233-240, 2008.

KAIDI, S. et al. Effect of conventional controlled-rate freezing and vitrification on morphology and metabolism of bovine blastocysts produced in vitro. Biology of Reproduction, v.65, p.1127-1134, 2001.

KASAI, M.; MUKAIDA, T. Cryopreservation of animal and human embryos by vitrification. Reproductive Biomedicine Online, v.9, p.164-170, 2004

LIEBERMANN, et al. Recent developpments in human oocyte, embryo and blastocyst vitrification: where are we now? Reproductive Biomedicine Online, v.7, p.623-633, 2003.
MAZUR, P. Cryobiology: the freezing of biological systems. Science, v.168, p.939-949, 1970

RALL, W.F.; FAHY, G.M. Ice-free cryopreservation of mouse embryos at $-196^{\circ} \mathrm{C}$ by vitrification. Nature, v.313, p.573$575,1985$.

ROBERSTON I.; NELSON R.E. Certification and identification of the embryo. In: STRINGFELLOW, D.A.; SEIDEL, S.M. (Eds.). Manual of the international embryo transfer society. 3.ed. Savoy: IETS, 1998. p.103-134.

SEKI, S.; MAZUR, P. Effect of warming rate on the survival of vitrified mouse oocytes and on the recrystallization of intracellular ice. Biology of Reproduction, v.79, p.727-737, 2008.

SIQUEIRA-PYLES, E.S.C. et al. Use of etilene-glycol, dimethilsulfoxid and dimethilformamide in the vitrification of bovine embryos in open pulled straws. Acta Scientiae Veterinariae, v.32, p.162, 2004

SQUIRES, E.L. et al. Evaluation of alternative cryoprotectants for preserving stallion spermatozoa. Theriogenology, v.62, p.1056-1065, 2004

SUKHNO, I.V.et al. The physicochemical characteristics of heteroassociates in the N,N-Dimethylformamide-Water System. Russian Journal of Physical Chemistry, v.82, p.717-722, 2008.

THOUAS, G.A. et al. Simplified technique for differential staining of inner cell mass and tropectoderm cells of mouse and bovine blastocyst. Reproductive BioMedicine Online v.3, n. 1, p.25-29, 2001.

VAJTA, G. et al. Open pulled straw (OPS) vitrification: a new way to reduce cryoinjuries of bovine ova and embryos. Molecular Reproduction and Development v.5, p.53-58, 1998.

VAJTA, G.; NAGY, Z.P. Are programable freezers still needed in the embryo laboratory? Review on vitrification. Reproductive BioMedicine Online, v.12, p.779-796, 2006.

WOODS, E.J. et al. Fundamental cryobiology of reproductive cells and tissues. Cryobiology, v.48, p.146-156, 2004. 